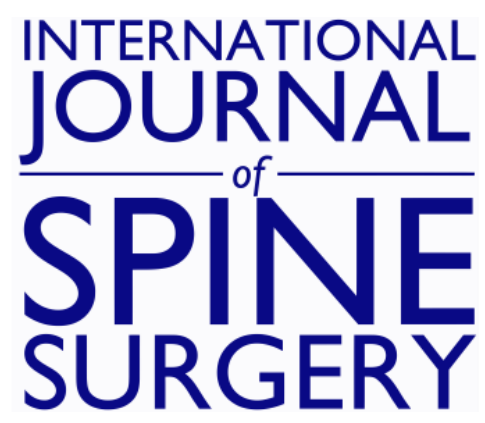

\title{
Skeletal Fluorosis With Thoracic Myelopathy: A Report of 2 Cases
}

Darshil Shah, Arjun Dhawale, Kshitij Chaudhary and Ajinkya Achalare

Int J Spine Surg 2021, 14 (s4) S89-S95

doi: https://doi.org/10.14444/7170

http://ijssurgery.com/content/14/s4/S89

This information is current as of April 26, 2023.

Email Alerts Receive free email-alerts when new articles cite this article. Sign up at:

http://ijssurgery.com/alerts

The International Journal of Spine Surgery

2397 Waterbury Circle, Suite 1,

Aurora, IL 60504, Phone: +1-630-375-1432

(C) 2021 ISASS. All Rightso Refseryedfom http://ijssurgery.com/ by guest on April 26, 2023 


\title{
Skeletal Fluorosis With Thoracic Myelopathy: A Report of 2 Cases
}

\author{
DARSHIL SHAH, MS, ARJUN DHAWALE, MS, DNB, KSHITIJ CHAUDHARY, MS, DNB, \\ AJINKYA ACHALARE, MS, DNB \\ Department of Orthopaedics, Sir H. N. Reliance Foundation Hospital, Mumbai, India
}

\begin{abstract}
Background: To report 2 different presentations of thoracic myelopathy with ossification of ligamantum flavum (OLF) due to fluorosis.

Methods: Two females presented with thoracic myelopathy secondary to spinal stenosis with OLF due to fluorosis. On examination, the first patient had a grade 4 power in both lower limbs with altered sensation below L1 dermatome. She had segmental OLF on magnetic resonance imaging and computed tomography and was treated with posterior thoracic laminectomy and recovered well. The second patient had a history of a prior thoracic laminectomy at another institution and presented with paraplegia with bladder involvement. Radiological investigations revealed a 3column injury at the level of D8/D9. This patient was treated with decompression and stabilization.

Results: The first patient recovered neurologically and regained independent ambulation while the second patient had a reduction in spasticity but no recovery of power or bladder function.

Conclusion: Different presentations and causes of myelopathy due to OLF should be recognized and treated. An unstable injury is very rare and should not be missed.

Other \& Special Categories

Keywords: fluorosis, thoracic, myelopathy, 3-column injury, ossification of posterior longitudinal ligament, ossification of ligamentum flavum, hyperostotic spine
\end{abstract}

\section{INTRODUCTION}

Skeletal fluorosis is an endemic disease that is a direct result of chronic ingestion of a large amount of fluoride that is incorporated into the bony hydroxyapatite, altering its mechanical properties. The fluorapatite formed results in an abnormal and poor quality of bone that is prone to fractures. ${ }^{1}$ The most evident changes are noted in the spine, wherein calcification of neural arch, osteophytes, and ossification of ligamentum flavum (OLF) result in canal stenosis and eventually a "poker back" spine. ${ }^{2}$ The cervical cord is affected earlier than the dorsal cord, ${ }^{3}$ and often the patient may present late with a picture of multiple-level cord involvement. Collectively, all of these factors increase the incidence of myelopathy and spinal fractures. Computed tomography $(\mathrm{CT})$ and magnetic resonance imaging (MRI) should be performed to identify the stenosis and rule out fractures of the spine that may not be evident on standard radiographs.

The objective of this report is to describe 2 different presentations of thoracic myelopathy with spinal stenosis due to fluorosis. One case required a standard thoracic spinal decompression, the second case had a missed 3-column injury of the thoracic spine and required revision decompression and stabilization to address the pathology, highlighting the need for a high index of suspicion for ruling out fractures in a hyperostotic spine, a very rare presentation in fluorosis.

\section{Case 1}

A 51-year-old female, hailing from Rajasthan, India, presented with low back pain that was insidious in onset, associated with bilateral lower limb weakness and numbness. She used a walker initially but gradually worsened and was nonambulatory 4 months before presentation. She also complained of lower limb stiffness that reduced following treatment with oral baclofen. There was no bowel/bladder involvement. Wasting of lower limbs was also noted. Findings are outlined in Table 1.

After informed consent and under general anesthesia and careful prone positioning on a spine frame, posterior thoracic laminectomy T9-T12 
Table 1. Case presentations.

\begin{tabular}{|c|c|c|}
\hline & Case 1 & Case 2 \\
\hline Age & $51 \mathrm{y}$ & $51 \mathrm{y}$ \\
\hline Sex & Female & Female \\
\hline \multirow[t]{2}{*}{ Symptoms } & Low back pain for $1 \mathrm{y}$ & Upper and lower back pain for $2-3 \mathrm{y}$ \\
\hline & Bilateral lower limb weakness for $8 \mathrm{mo}$ & Bilateral lower limb weakness for $9 \mathrm{mo}$ \\
\hline $\begin{array}{l}\text { Ambulatory status at } \\
\text { presentation }\end{array}$ & Nonambulatory & Nonambulatory \\
\hline Prior intervention & Tab baclofen & T10- T11 laminectomy 5 mo prior at other hospital \\
\hline Signs & $\begin{array}{l}\text { Thoracic and lumbar tenderness } \\
\text { Decreased range of motion of entire spine }\end{array}$ & Thoracic and lumbar tenderness \\
\hline \multicolumn{3}{|c|}{ 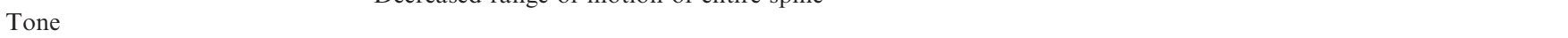 } \\
\hline Upper limb & Normal & Normal \\
\hline Lower limb & Increased & Reduced \\
\hline \multicolumn{3}{|l|}{ Sensory } \\
\hline Upper limb & No sensory deficit & No sensory deficit \\
\hline Lower limb & Reduced sensation below L1 dermatome bilaterally & Reduced sensation below T11 dermatome \\
\hline \multicolumn{3}{|l|}{ Motor } \\
\hline Upper limb & Grade 5 power & Grade 5 power \\
\hline Lower limb & Grade 4 power bilaterally & Grade 0 power bilaterally \\
\hline \multicolumn{3}{|l|}{ Reflexes } \\
\hline Upper limb & Normal & Normal \\
\hline Lower limb & $\begin{array}{l}\text { Knee and ankle } \\
\text { reflex brisk } \\
\text { Upgoing plantars }\end{array}$ & All reflexes grade 0 \\
\hline \multicolumn{2}{|l|}{ Preoperative } & $\mathrm{B}$ \\
\hline $\mathrm{X}$ - ray & $\begin{array}{l}\text { Generalized sclerosis of entire spine with osteophytes } \\
\text { Interspinous ligament ossification noted (Figure 1A) }\end{array}$ & $\begin{array}{l}\text { Increased density of vertebral bodies } \\
\text { Multilevel bridging syndesmophytes at lower dorsal } \\
\text { and entire lumbar spine (Figure } 2 \mathrm{~A} \text { ) }\end{array}$ \\
\hline MRI scan & $\begin{array}{l}\text { Spinal stenosis at the level of } \mathrm{T} 10-\mathrm{T} 11 \text { with cord } \\
\text { indentation (Figure 1B) }\end{array}$ & $\begin{array}{l}\text { Focal stenosis at T3 and T11- T12, 3-column injury } \\
\text { at T11- T12 vertebra (Figure 2B) }\end{array}$ \\
\hline CT scan & OLF causing T9- T12 stenosis (Figure 1C) & $\begin{array}{l}\text { Focal stenosis at T3 and T11- T12 with 3-column } \\
\text { fracture (Figure } 2 \mathrm{C} \text { ) }\end{array}$ \\
\hline Surgical treatment offered & $\begin{array}{l}\text { Posterior thoracic T9- T12 laminectomy (Figure 1D, } \\
\text { E) }\end{array}$ & $\begin{array}{l}\text { T8- L3 posterior stabilization with } \mathrm{T} 10-\mathrm{T} 12 \\
\text { decompression (Figure 2D) } \\
\text { T1- T3 decompression }\end{array}$ \\
\hline Intraoperative complications & Dural tear & Dural tear \\
\hline $\begin{array}{l}\text { ASIA postoperative score } \\
\text { Postoperative }\end{array}$ & $\mathrm{E}$ & $\mathrm{B}$ \\
\hline Follow- up & $1 \mathrm{y}$ & $1 \mathrm{y}$ \\
\hline
\end{tabular}

Abbreviations: ASIA, American Spinal Injury Association; CT, computed tomography; MRI, magnetic resonance imaging; CT, computed tomography; OLF, ossification of ligamentum flavum.

(levels of severe stenosis T10-T11) was performed with a Misonix ultrasonic diamond burr (Misonix, Farmingdale, New York) and thin foot plate Kerrison rongeur. At areas of dural adherence with calcified tissue, the tissue was released from the surrounding bone, and floating fragments were created to obtain adequate decompression. At the level of T10, incidental durotomy occurred due to removal of adherent calcified tissue that was sealed with dural sealants (Durafoam and $\mathrm{T}$ seal). The posterior ligaments (ie, interspinous, supraspinous, and ligamentum flavum) were noted to be calcified (Figure 1D). The patient showed significant neurological improvement in the postoperative period and was mobilized with a walker on day 6 post surgery. At 1 year follow-up, the patient had achieved neurological recovery with persistence of mild stiffness of the lower limbs. The cervical and lumbar stenosis may need to be addressed in the future.

\section{Case 2}

A 51-year-old female, residing in the same fluorosisendemic area, presented with upper and lower back pain 3 years ago and gradual onset of bilateral lower limb weakness 9 months back; she was completely bedridden for the past 6 months. She underwent a T10-T11 laminectomy 5 months ago at another local hospital. However, there was no resolution of symptoms following initial surgery. She had thoracolumbar tenderness with a well-healed midline surgical scar over the thoracic region. The patient was catheterized due to bladder involvement since few months. Findings are summarized in Table 1.

Radiographs of the spine revealed osteosclerosis along with multi level bridging syndesmophytes at 

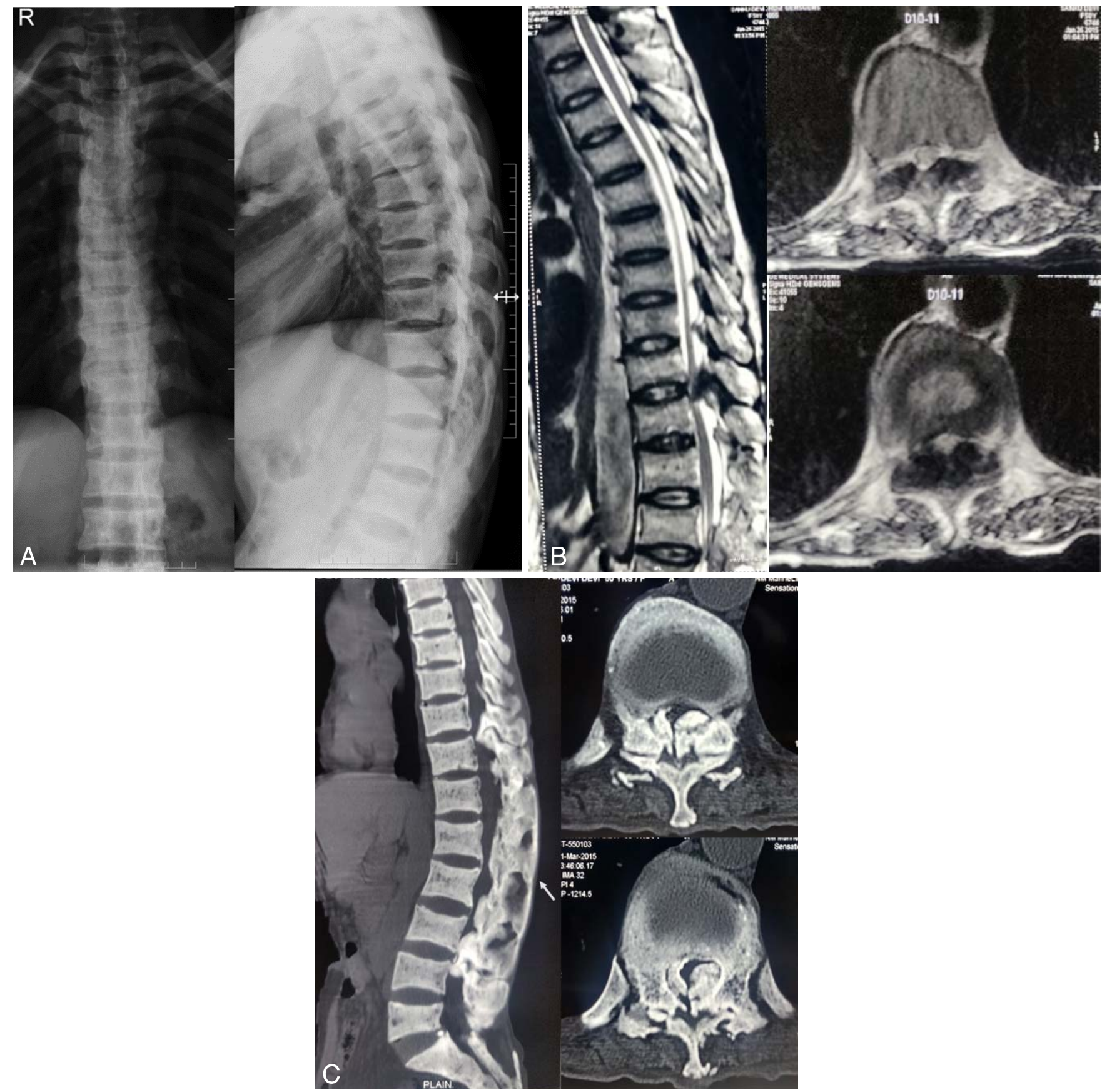

Figure 1. (A) Case 1: Preoperative radiograph of dorsal spine, anteroposterior and lateral. (B) Case 1: Sagittal and axial magnetic resonance image of thoracolumbar spine showing cord compression at T10-T11. (C) Case 1: Sagittal and axial computed tomogram with stenosis at T10-T11 (ossification marked with arrows). (D) Case 1: Intraoperative pictures showing calcification of interspinous ligaments (arrow) prior to decompression and adequate decompression after laminectomy (arrow). (E) Case 1: Postoperative radiograph of dorsal spine, anteroposterior and lateral.

the lower dorsal and entire lumbar spine (Figure 2A). Paravertebral ossification was present at T11T12. Spine MRI and CT showed focal stenosis at T3 and T11-T12 with a 3-column spinal injury at the level of T11-T12 (Figure 2B, C).

T8-L3 posterior stabilization was done (Figure 2D) with decompression performed at T10-T12 with a Misonix burr. Incidental durotomy occurred, which was repaired with 5-0 prolene and reinforced with G Patch and Reliseal fibrin glue. Stenosis at the level of T1-T3 was also addressed via a separate incision using the Misonix burr and careful use of a thin foot plate Kerrison rongeur. There was ossification of interspinous ligaments with hard, chalky bone, corroborating diagnosis. She had a candida fungal urinary tract infection that was 

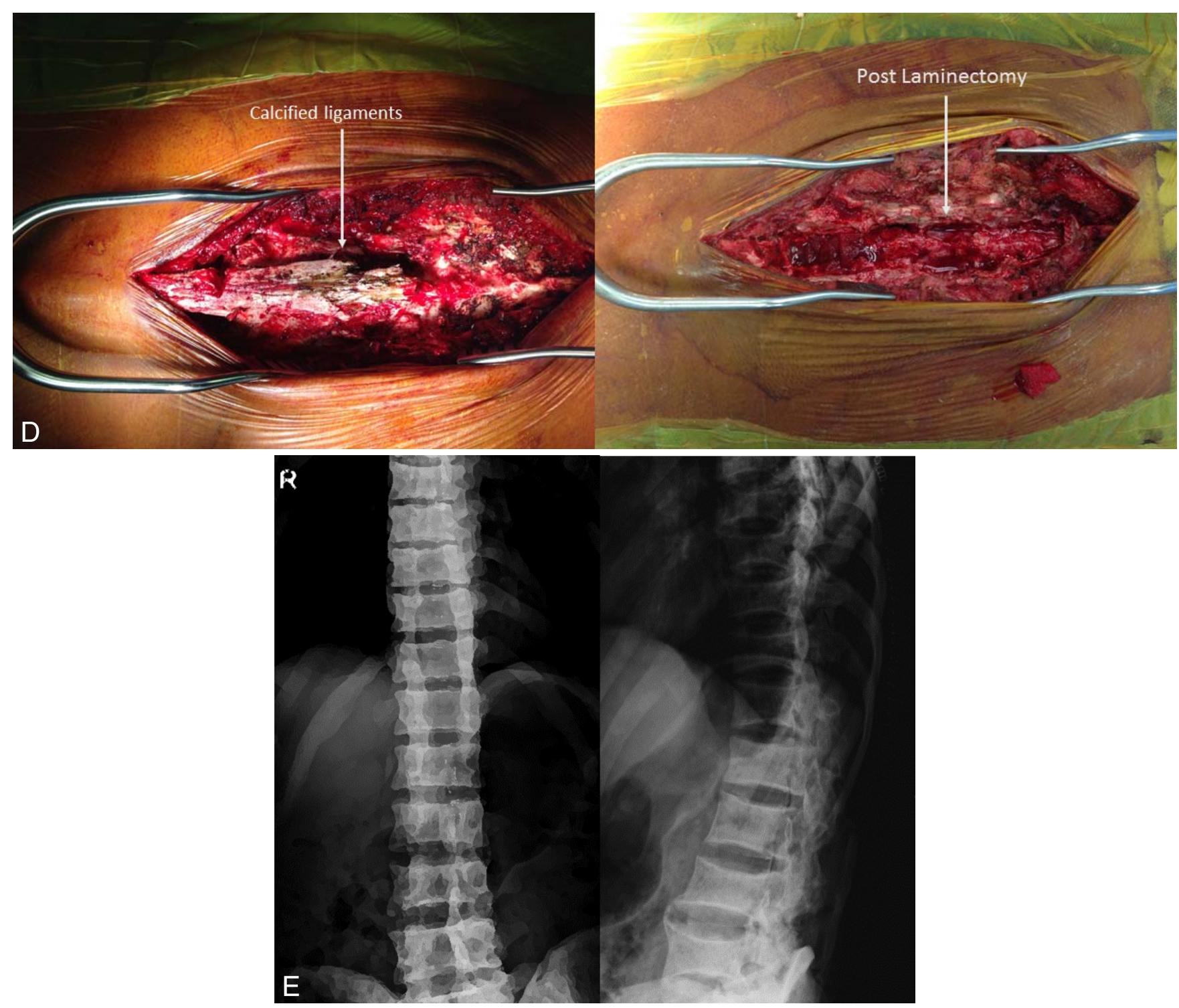

Figure 1. Continued.

treated with intravenous antifungal medications. The back pain had reduced following surgery with marginal improvement in sensation compared to preoperatively. There was no return in power or bladder function at 1 year follow-up, although she was able to sit independently. She needed intermittent self-catheterization.

\section{DISCUSSION}

The effects of fluoride, though found commonly in the environment, are often overlooked by physicians. Along with the skeletal and bone tissues, fluoride exerts its effect on the cardiovascular, nervous, gastrointestinal, endocrine, and reproductive systems. ${ }^{4}$ Ninety-nine percent of the fluoride burden is borne by the skeletal system. ${ }^{5,6}$ In the skeletal system, chronic fluoride ingestion causes skeletal fluorosis, which results in osteosclerosis, degenerative joint changes, and ligament calcification. $^{7,8,9}$ It causes a substitution of the hydroxyl group in hydroxyapatite and leads to fluorapatite formation. ${ }^{10}$ The resultant fluorapatite is resistant to the resorptive effect of parathyroid hormone. This alteration leads to changes in the crystallinity of bone, in turn resulting in a reduction in the mechanical strength of the bone. Fluorosis results in calcification of posterior spinal ligaments (ie, supraspinous, interspinous ligaments). Although rare, calcification of ligamentum flavum secondary to fluorosis has been documented previously ${ }^{11}$ and is also noted here. OLF is also seen in other 

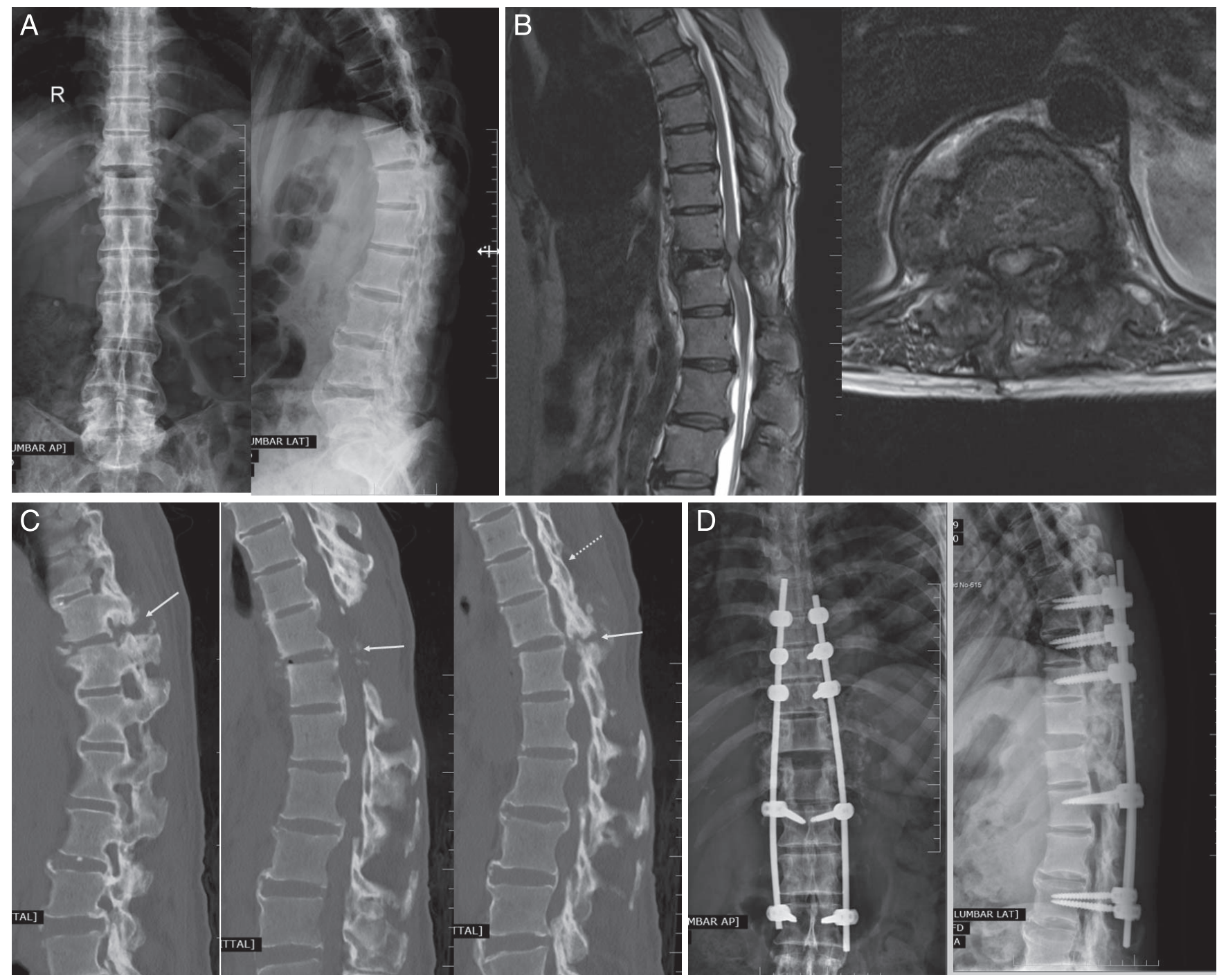

Figure 2. (A) Case 2: Preoperative radiograph of dorsal spine, anteroposterior lateral. (B) Case 2: Sagittal and axial magnetic resonance image of thoraco-lumbar spine showing stenosis at T11-T12. (C) Case 2: Sagittal and parasagittal computed tomogram showing 3-column injury (arrows) and previous laminectomy; dotted arrow shows ossification of ligaments. (D) Case 2: Postoperative radiograph of thoraco-lumbar spine.

disorders (Table 2). Although a rare entity, OLF should be considered in the differential diagnosis for myelopathic patients living in fluorosis-endemic regions or for those with impaired renal function. The probable underlying pathogenesis is believed to be overexpression of c-fos and c-jun proteins. ${ }^{10}$

Both cases presented with neurological deficits secondary to compressive thoracic myelopathy due

Table 2. Causes of ossification of ligamentum flavum.

\begin{tabular}{l}
\hline Causes \\
\hline 1. Calcium pyrophosphate dihydrate deposition disease \\
2. X- linked hypophosphatemic rickets \\
${ }^{13}$ \\
3. Osteoblastoma \\
4. Osteoid osteoma \\
5. En plaque meningioma adjacent to ligamentum flavum ${ }^{15}$ \\
6. Paget's disease ${ }^{16}$ \\
7. Fluorosis \\
\hline
\end{tabular}

to fluorosis. Although myelopathy secondary to fluorosis is more common in males, ${ }^{10}$ both were females. A full spine screening MRI should always be performed to identify noncontiguous areas of stenosis that may need treatment. Nonoperative treatment is not recommended for symptomatic patients with OLF. ${ }^{9}$ We addressed the compression with a standard posterior approach and performed decompression using the Misonix ultrasonic BoneScalpel. It provided better precision, and its "oscillating blade-micro motion" mechanism of action ensured safety of the spinal cord and dura. The oscillating motion, much like a "plaster cutter" ensures accurate dissection of bone and calcified soft tissue with minimal risk to the dura and spinal cord. We used the "floating island technique," ${ }^{17}$ wherein 
Table 3. Previous reports of thoracic fractures in patients with ossified posterior arch.

\begin{tabular}{|c|c|c|c|c|}
\hline Author & $\begin{array}{l}\text { Sample Size } \\
\text { (Thoracic } \\
\text { Fracture) }\end{array}$ & Fracture & Treatment & Outcome \\
\hline Dumpa et $\mathrm{al}^{18}$ & 1 & $\begin{array}{l}\text { Chance fracture at T11 in a previously } \\
\text { instrumented vertebra }\end{array}$ & Extension of construct to $\mathrm{T} 8-\mathrm{T} 12$ & Uneventful recovery \\
\hline Kasukawa et al ${ }^{19}$ & 5 & $\begin{array}{l}\mathrm{T} 10=1 \\
\mathrm{~T} 11=1 \\
\mathrm{~T} 12=3\end{array}$ & $\begin{array}{l}\text { Laminectomy and posterior fusion } \\
(\mathrm{n}=3) \\
\text { Laminectomy }+ \text { vertebroplasty and } \\
\quad \text { fusion }(\mathrm{n}=2)\end{array}$ & Persistence of inability to walk \\
\hline Katoh et $\mathrm{al}^{20}$ & 17 & Caron type 1 fracture & Posterior fusion & \\
\hline Altun et $\mathrm{al}^{21}$ & 1 & $\begin{array}{l}\text { T5 chance fracture in patient with } \\
\text { ankylosing spondylitis }\end{array}$ & TLSO & $\begin{array}{l}\text { Admission Frankel score: } 5 \\
\text { Follow- up Frankel score: } 11\end{array}$ \\
\hline Sapkas et $\mathrm{al}^{22}$ & 4 & $\begin{array}{l}\text { 1. T8- T9/B.1.1.1 } \\
\text { 2. T10- T11/C.2.1.3 } \\
\text { 3. T11- T12/B.1.1.1 } \\
\text { 4. T12- L1/B.1.1.1 }\end{array}$ & $\begin{array}{l}\text { 1. Posterior instrumentation T6- T11 } \\
\text { 2. Posterior instrumentation T8- L1 } \\
\text { 3. Posterior instrumentation T10- L2 } \\
\text { 4. Posterior instrumentation T10- L2 }\end{array}$ & $\begin{array}{l}\text { Preoperative/postoperative } \\
\text { Frankel score } \\
\text { 1. E/E } \\
\text { 2. A/A } \\
\text { 3. E/E } \\
\text { 4. E/E }\end{array}$ \\
\hline An et $\mathrm{al}^{23}$ & 1 & $\begin{array}{l}\text { T11 hyperextension } 3 \text {-column injury } \\
\text { (old T11 fracture which was treated } \\
\text { with pedicle screw fixation) }\end{array}$ & $\begin{array}{l}\text { Previous screw removal, T10- L1 } \\
\text { pedicle screw fixation, bilateral } \\
\text { laminectomy T10, T11, } \\
\text { T11- T12 corpectomy and mesh cage }\end{array}$ & $\begin{array}{l}\text { American Society of } \\
\text { Anesthesiologists grade } \\
\text { Preoperatively: grade A } \\
\text { Postoperatively: grade A }\end{array}$ \\
\hline Reinhold et $\mathrm{al}^{24}$ & 1 & $\begin{array}{l}\text { Iatrogenic } \mathrm{T} 12 \text { hyperextension } \\
\text { fracture-dislocation while patient } \\
\text { positioning }\end{array}$ & $\begin{array}{l}\text { T9- L3 monoaxial pedicle screw } \\
\text { fixation }\end{array}$ & $\begin{array}{l}\text { Neurology intact throughout } \\
\text { treatment }\end{array}$ \\
\hline
\end{tabular}

no attempt was made to remove tissues that had excessively adhered to the dura. Instead, we detached the tissue from the surrounding bone, thereby creating a "floating island" of tissue. Despite utilizing the above-mentioned techniques, dural tears occurred in both cases. This indicates excessive calcification and adherence of surrounding structures to the dura; therefore, all resources should be on hand while managing such cases. Additionally, it is often essential to perform multilevel decompression in cases of spinal fluorosis to obtain a good functional outcome. If a selective decompression of the most symptomatic region is performed, close follow-up is essential to review for any new neurological findings due to the increase in the cervical and lumbar stenosis.

The resultant effect of calcification of posterior spinal ligaments is a stiff spine, which makes it more prone to fractures and has been rarely reported in fluorosis. In case 2 , the patient presented with a fracture of the thoracic spine with a delayed diagnosis and a poor neurological outcome. We are aware of one such case of skeletal fluorosis reported where chance fracture occurred through previously instrumented pedicle. ${ }^{18}$ The fracture pattern suggested a hyperextension injury, similar to ankylosing spondylitis. Such fractures should be managed with extended instrumentation of at least 2 segments above and below the fracture. This ensures stability and a good functional outcome. Patients with chronic myelopathy along with a 3-column injury seldom have good neurological improvement following surgery. ${ }^{19}$ Table 3 outlines the management of various types of thoracic fractures associated with ankylosing spondylitis, ossification of posterior longitudinal ligament, and diffuse idiopathic skeletal hyperostosis. Fractures through the ossification of posterior longitudinal ligament and OLF are often missed due to low index of suspicion, leading to inadequate treatment and unsatisfactory functional outcomes. In a study done by Katoh et $\mathrm{al}^{20}$ a delay in diagnosis occurred in $76.6 \%$ of the cases, where $57.45 \%$ of the delay was due to missed diagnosis by the physician. Therefore, we suggest a thorough review of PACS with scrolling of thin-cut CT and MRI scans to look for hyperextension injuries, loss of 3-column continuity, and opening up of the disc space anteriorly. Furthermore, the need for annual physical examinations of the spine should be emphasized in patients with fluorosis. After all, prevention is better than the cure.

\section{CONCLUSION}

Two presentations of thoracic myelopathy in fluorosis are described: a relatively more common OLF with multilevel stenosis treated with decompression alone using ultrasonic burr and a relatively rare unstable fracture treated with decompression and longer posterior instrumentation. 


\section{REFERENCES}

1. Teotia SP, Teotia M, Singh KP. Highlights of forty years of research on endemic skeletal fluorosis in India. Paper presented at: 4th International Workshop on Fluorosis Prevention and Defluoridation of Water; March 2-6, 2004; Colombo, Sri Lanka.

2. Ramakrishna K, Sasikiran NO. Fluorosis - an update. Int J Res Pharm Biomed Sci. 2013;4(1):1084-1088.

3. Kurdi MS. Chronic fluorosis: the disease and its anesthetic implications. Indian J Anesth. 2016;60(3):157-162. doi:10.4103/ 0019-5049.177867

4. Wei W, Pang S, Sun D. The pathogenesis of endemic fluorosis: research progress in the last 5 years. $J$ Cell Mol Med. 2019;23(4):2333-2342. doi:10.1111/jcmm.14185

5. Everette ET. Fluoride's effects on the formation of teeth and bones, and the influence of genetics. $J$ Dent Res. 2011;90(5):552-560. doi:10.1177/0022034510384626

6. Whitford GM. Fluoride metabolism and excretion in children. J Public Health Dent. 1999;59(4):224-228. https://doi. org $/ 10.1111 / \mathrm{j} .1752-7325.1999 . t b 03273 . x$

7. Cao J, Zhao Y, Liu J, et al. Brick tea fluoride as a main source of adult fluorosis. Food Chem Toxicol. 2003;41(131):535542. doi:10.1016/s0278-6915(02)00285-5

8. Gupta N, Chhabra P. Image diagnosis: dental and skeletal fluorosis. Perm J. 2016;20(1):e105-e106. doi:10.7812/TPP/15048

9. Wang W, Kong L, Zhao H, Dong R, Li J, Jia Z. Thoracic ossification of ligamentum flavum caused by skeletal fluorosis. Eur Spine J. 2007;16(8):1119-1128. doi:10.1007/s00586-0060242-5

10. Muthukumar N. Ossification of the ligamentum flavum as a result of fluorosis causing myelopathy: report of two cases. Neurosurgery. 2005;56(3):E622. doi:10.1227/01.NEU.0000154062. 14313.6D

11. Gupta RK, Agarwal P, Kumar S, Surana PK, Lal JH, Misra UK. Compressive myelopathy in fluorosis: MRI. Neuroradiology. 1996;38(4):338-342. doi:10.1007/BF00596584

12. Muthukumar N, Karuppaswamy U. Tumoral calcium pyrophosphate dihydrate deposition disease of the ligamentum flavum. Neurosurgery. 2003;53(1):103-109. doi:10.1227/01.neu. 0000068861.47199.a8

13. Soehle M, Casey AT. Cervical spinal cord compression attributable to a calcified intervertebral disc in a patient with $\mathrm{X}$-linked hypophosphatemic rickets: case report and review of the literature. Neurosurgery. 2002;51(1):239-243. doi:10.1097/ 00006123-200207000-00038

14. Okuda S, Myoui A, Nakase T, Wada E, Yonenobu K, Yoshikawa H. Ossification of the ligamentum flavum associated with osteoblastoma: a report of three cases. Skeletal Radiol. 2001;30(7):402-406. https://doi.org/10.1007/s002560100324

15. Gamache FW Jr, Wang JC, Deck M, Heise C. Unusual appearance of an en plaque meningioma of the cervical spinal canal: a case report and literature review. Spine. 2001;26(5):E87-E89. doi:10.1097/00007632-200103010-00004

16. Hepgul K, Nicoll JA, Coakham HB. Spinal cord compression due to pagetic spinal stenosis with involvement of extradural soft tissues: a case report. Surg Neurol. 35(2):143146, 1991. doi:10.1016/0090-3019(91)90267-d

17. Modi JV, Tankshali KV, Patel ZM, Shah BH, Gol AK. Management of acquired compressive myelopathy due to spinal fluorosis. Indian J Orthop. 2019;53(2):324-332. doi:10.4103/or tho.IJOrtho_570_17

18. Dumpa SR, Aiyer SN, Rajoli SR, et al. Delayed chance fracture pattern injury in a case of skeletal fluorosis. Eur Spine J. 2018;27(S3):264-269. doi:10.1007/s00586-017-5117-4

19. Kasukawa Y, Miyakoshi N, Hongo M, et al. Surgical results of patients with myelopathy due to ossification of the ligamentum flavum with ossification of the posterior longitudinal ligament or a vertebral fracture at the same level of the thoracic spine: a retrospective comparative study. Asian Spine J. 2019;13(5):832-841. doi:10.31616/asj.2018.0278

20. Katoh H, Okada E, Yoshii T, et al. A comparison of cervical and thoracolumbar fractures associated with diffuse idiopathic skeletal hyperostosis - a nationwide multicenter study. J Clin Med. 2020;9(1):208. doi:10.3390/jcm9010208

21. Altun I, Yuksel KZ. Ankylosing spondylitis: patterns of spinal injury and treatment outcomes. Asian Spine $J$. 2016;10(4):655-662. doi:10.4184/asj.2016.10.4.655

22. Sapkas G, Kateros K, Papadakis SA, et al. Surgical outcome after spinal fractures in patients with ankylosing spondylitis. BMC Musculoskelet Disord. 2009;10(1):96. doi:10. 1186/1471-2474-10-96

23. An SB, Kim KN, Chin DK, Kim KS, Cho YE, Kuh SU. Surgical outcomes after traumatic vertebral fractures in patients with ankylosing spondylitis. $J$ Korean Neurosurg Soc. 2014;56(2):108-113. doi:10.3340/jkns.2014.56.2.108

24. Reinhold M, Knop C, Kneitz C, Disch A. Spine fractures in ankylosing diseases: recommendations of the Spine Section of the German Society for Orthopaedics and Trauma (DGOU). Global Spine J. 2018;8(suppl 2):56S-68S. doi:10.1177/2192568217736268

Disclosures and COI: There are no financial disclosures, conflicts of interest, or support statements by any author.

Corresponding Author: Darshil Shah, MS, Department of Orthopaedics, Sir H. N. Reliance Foundation Hospital, Prarthana Samaj, Charni Road East, Mumbai 400004, Maharashtra, India. Phone: +91 22-61305047; E-mail: drshahdarshil@ gmail.com.

Published 11 February 2021

This manuscript is generously published free of charge by ISASS, the International Society for the Advancement of Spine Surgery. Copyright (C 2020 ISASS. To see more or order reprints or permissions, see http://ijssurgery.com. 